\title{
UPAYA MENINGKATKAN HASIL BELAJAR ILMU PENGETAHUAN ALAM PADA MATERI BENDA DAN SIFATNYA DENGAN MENGGUNAKAN METODE EKSPERIMEN SISWA KELAS IV SD NEGERI 163083 TEBING TINGGI
}

Masdiana Manurung*

Surel: masdianamanurung13@gmail.com

\begin{abstract}
This class action research uses the Lewins model, in which each cycle consists of activities of planning, implementation, observation and reflection. This research was conducted in 2 cycles. The subjects in this study were fourth grade students of 163083 Public Elementary School Tebing Tinggi city, totaling 22 students. This study uses qualitative descriptive analysis techniques. The results of the classical completeness of student learning reached 59.09\% with an average of 65.90 in the first cycle and increased to $100 \%$ with an average of 89.54 in the second cycle.
\end{abstract}

Keywords: Learning, Outcomes, Poetry, Techniques

\begin{abstract}
ABSTRAK
Penelitian tindakan kelas ini menggunakan model Lewins, dimana dalam setiap siklusnya terdiri dari kegiatan perencanaan, pelaksanaan, observasi dan refleksi. Penelitian ini dilaksanakan sebanyak 2 siklus. Subjek pada penelitian ini adalah siswa kelas IV SD Negeri 163083 kota Tebing Tinggi yang berjumlah 22 siswa. Penelitian ini menggunakan teknik analisis dekriptif kualitatif. Hasil ketuntasan klasikal belajar siswa yang mencapai $59,09 \%$ dengan rata-rata 65,90 pada siklus I dan meningkat menjadi $100 \%$ dengan rata-rata 89,54 pada siklus II.
\end{abstract}

Kata Kunci: Hasil Belajar, Puisi, Teknik

\section{PENDAHULUAN}

Belajar adalah suatu proses yang kompleks yang terjadi pada semua orang dan berlangsung seumur hidup, dari ia masih bayi sampai ke liang lahat nanti. Salah satu pertanda bahwa seseorang telah belajar sesuatu adalah adanya perubahan tingkah laku dalam dirinya. Perubahan tingkah laku tersebut baik yang bersifat pengetahuan (kognitif) dan keterampilan (psikomotor) maupun yang menyangkut nilai dan sikap (afektif).

Kegiatan belajar bisa dilakukan dimana saja. Sekolah merupakan salah satu lembaga dimana manusia belajar. Kegiatan pembelajaran di sekolah adalah suatu proses interaksi atau hubungan timbal balik antara guru dan peserta didik dalam satuan pembelajaran. Guru sebagai salah satu komponen 
dalam proses belajar menganjar merupakan pemegang peran yang sangat penting. Guru bukan hanya sekedar penyampai materi saja, tetapi lebih dari itu guru dapat dikatakan sebagai sentral pembelajaran.

Hal ini terlihat dari rendahnya prestasi belajar peserta didik baik dalam ulangan harian, ulangan semester, maupun ujian akhir sekolah, padahal dalam pelaksanaan proses pembelajaran di kelas biasanya guru memberikan latihan soal. Penyebabnya dapat berasal dari peserta didik, guru maupun sarana dan prasarana yang ada, minat dan motivasi peserta didik yang rendah, kinerja guru yang rendah, serta sarana dan prasarana yang kurang memadai akan menyebabkan siswa menjadi tidak bersemangat dalam belajar bahkan berkesan membosankan dan ribut pembelajaran menjadi kurang efektif.

Hal tersebut dirasakan juga oleh peneliti di SD Negeri 163083 dimana tempat peneliti bertugas. Dari 22 siswa kelas IV tahun ajaran 2016/2017 sebagian besar siswa tidak memahami materi tentang sifat benda, benda yang dapat larut dan tidak dapat larut dalam air, serta perubahan wujud benda. Permasalahan ini dikarenakan selama ini ketika mengajarkan materi benda dan sifatnya, guru hanya bersifat teori sehingga siswa sulit memahami materi benda dan sifatnya karena diajarkan oleh guru secara abstrak. Keadaan tersebut membuat tingkat pemahaman siswa terhadap materi benda dan sifatnya menjadi sangat rendah.

Keadaan yang demikian ini tidak bias dibiarkan berlarut larut dan perlu dicari solusi untuk mengatasinya, sehingga tingkat pemahaman siswa terhadap materi benda dan sifatnya bisa menjadi lebih baik dan hasil belajar menjadi lebih meningkat.

Penggunaan metode eksperimen diharapkan dapat meningkatkan aktivitas peserta didik dalam proses belajar mengajar sehingga dalam proses belajar mengajar itu aktivitasnya tidak hanya didominasi oleh guru, dengan demikian peserta didik akan terlibat secara fisik, emosional dan intelektual yang pada gilirannya diharapkan konsep materi yang sedang diajarkan tidak menjadi abstrak bagi siswa karena siswa merasakan langsung proses yang sedang dipelajarinya tersebut. Berdasarkan uraian dari latar belakang tersebut di atas maka peneliti dalam penelitian ini memilih judul "Upaya Meningkatkan Hasil Belajar IPA Pada Materi Benda dan Sifatnya Dengan Menggunakan Metode Eksperimen Siswa Kelas IV SD Negeri 163083 Tahun Pembelajaran 2016/2017".

Berdasarkan latar belakang yang telah diuraikan diatas maka dapat diidentifikasi masalah dalam penelitian ini, yaitu:

1. Pemahaman peserta didik pada mata pelajaran IPA masih rendah.

2. Pembelajaran IPA diajarkan guru 
sebatas ceramah sehingga konsep pembelajaran IPA menjadi hal yang abstrak bagi siswa.

3. Kurang aktifnya peserta didik saat pembelajaran yang nampak dari masih banyak peserta didik yang tidak berani bertanya dan berinteraksi dengan guru saat pembelajaran.

4. Peserta didik masih menganggap pembelajaran IPA merupakan pembelajaran yang membosankan.

Berdasarkan latar belakang dan identifikasi masalah di atas, maka batasan masalah dalam penelitian ini adalah peningkatan hasil belajar IPA pada materi benda dan sifatnya dengan menggunakan metode eksperimen.

Berdasarkan latar belakang tersebut, rumusan masalah dalam penelitian ini adalah sebagai berikut : "Apakah dengan menggunakan metode eksperimen dapat meningkatkan hasil belajar IPA pada materi benda dan sifatnya siswa kelas IV SD Negeri 163083 Tahun Pembelajaran 2016/2017?

Penelitian ini bertujuan untuk meningkatkan hasil belajar IPA pada materi benda dan sifatnya dengan menggunakan metode eksperimen

Penelitian ini diharapkan dapat bermanfaat sebagai berikut :

\section{Bagi Siswa}

Penelitian ini bermanfaat bagi siswa karena dapat meningkatkan hasil belajar ilmu pengetahuan alam pada materi benda dan sifatnya.
Membantu siswa berfikir kritis, rasional dan kreatif dan dapat memperoleh informasi dan pengalaman langsung melalui percobaan. Memberi peluang kepada siswa untuk lebih aktif mengembangkan potensi dirinya terutama dalam memberi pendapatpendapat yang konstruktif positif untuk memecahkan masalah dalam kehidupannya sehari-hari

Manfaat Bagi Guru

Meningkatkan kualitas guru dalam melaksanakan tugas mengajar terutama dalam mengajar ilmu pengetahuan alam ( IPA ). Merangsang guru-guru yang lain untuk melakukan pembelajaran yang kreatif dan menyenangkan bagi siswa.

Manfaat Bagi Sekolah

Meningkatkan hasil belajar ilmu pengetahuan alam ( IPA) di SD Negeri 163083 kota Tebing Tinggi, sehingga mampu bersaing dengan sekolah sekolah yang lain.

Belajar pada prinsipnya adalah proses perubahan tingkah laku sebagai akibat dari interaksi antara peserta didik dengan sumber-sumber atau obyek belajar baik secara sengaja dirancang atau tanpa sengaja dirancang. Belajar ada kaitannya dengan usaha atau rekayasa pembelajar. Dari segi peserta didik, belajar yang dialaminya sesuai dengan pertumbuhan jasmani dan perkembangan mental, akan menghasilkan hasil belajar sebagai dampak pengiring, selanjutnya, 
dampak pengiring tersebut akan menghasilkan program belajar sendiri sebagai perwujudan emansipasi peserta didik menuju kemandirian.

Dari segi guru, kegiatan belajar peserta didik merupakan akibat dari tindakan pendidikan atau pembelajaran. Proses belajar peserta didik tersebut menghasilkan perilaku yang dikehendaki, suatu hasil belajar sebagai dampak pengajaran. (Dimyati \& Mudjiono, 2002). Pasal 1 Undang-undang No. 20 tahun 2000 tentang pendidikan nasional menyebutkan bahwa pembelajaran adalah proses interaksi peserta didik dengan pendidik dan sumber belajar pada suatu lingkungan belajar.

Jadi pembelajaran adalah proses yang disengaja yang menyebabkan peserta didik belajar pada suatu lingkungan belajar untuk melakukan kegiatan pada situasi tertentu. Belajar dapat dilakukan di sembarang tempat, kondisi, dan waktu. Cepatnya informasi lewat radio, televisi, film, internet, surat kabar, majalah, dapat mempermudah belajar. Meskipun informasi dapat dengan mudah diperoleh, tidak dengan sendirinya seseorang terdorong untuk memperoleh pengetahuan, pengalaman, pengetahuan dan ketrampilan daripadanya.

Guru profesional memperlukan pengetahuan dan keterampilan pendekatan pembelajaran agar mampu mengelola berbagai pesan sehingga peserta didik terbiasa belajar sepanjang hayat. Pendekatan pembelajaran dapat berarti anutan pembelajaran yang berusaha meningkatkan kemampuankemampuan kognitif, afektif dan psikomotorik peserta didik dalam pengolahan pesan sehingga tercapai sasaran belajar. Pendekatan pembelajaran dengan pengorganisasian peserta didik dapat dilakukan dengan pembelajaran secara individual, pembelajaran secara kelompok, dan pembelajaran secara klasikal. (Dimyati \& Mudjiono, 2002). Dari sisi peserta didik yang bertindak belajar akan menimbulkan masalah-masalah internal belajar. Dari sisi guru, yang memusatkan perhatian pada peserta didik yang belajar maka akan muncul

IPA didefiniksan sebagai suatu kumpulan pengetahuan yang tersusun secara alam. Perkembangan IPA tidak hanya ditandai dengan adanya fakta, tetapi juga oleh adanya metode ilmiah dan sikap ilmiah. Metode ilmiah dan pengamatan ilmiah menekankan pada hakikat IPA. Secara rinci hakikat IPA menurut Bridgman (dalam Lestari, 2002: 7) adalah sebagai berikut:

1. Kualitas; pada dasarnya konsepkonsep IPA selalu dapat dinyatakan dalam bentuk angka-angka.

2. Observasi dan Eksperimen; merupakan salah satu cara untuk dapat memahami konsep-konsep IPA secara tepat dan dapat diuji kebenarannya. 
3. Ramalan (prediksi); merupakan salah satu asumsi penting dalam IPA bahwa misteri alam raya ini dapat dipahami dan memiliki keteraturan. Dengan asumsi tersebut lewat pengukuran yang teliti maka berbagai peristiwa alam yang akan terjadi dapat diprediksikan secara tepat.

4. Progresif dan komunikatif; artinya IPA itu selalu berkembang ke arah yang lebih sempurn dan penemuanpenemuan yang ada merupakan kelanjutan dari penemuan sebelumnya. Proses; tahapan-tahapan yang dilalui dan itu dilakukan dengan menggunakan metode ilmiah dalam rangkan menemukan suatu kebernaran.

5. Universalitas; kebenaran yang ditemukan senantiasa berlaku secara umum.

Belajar dapat membawa suatu perubahan pada individu yang belajar. Perubahan ini merupakan pengalaman tingkah laku dari yang kurang baik menjadi lebih baik. Pengalaman dalam belajar merupakan pengalaman yang dituju pada hasil yang akan dicapai peserta didik dalam proses belajar di sekolah. Menurut Poerwodarminto (1991: 768), prestasi belajar adalah hasil yang dicapai (dilakukan, dekerjakan), dalam hal ini prestasi belajar merupakan hasil pekerjaan, hasil penciptaan oleh seseorang yang diperoleh dengan ketelitian kerja serta perjuangan yang membutuhkan pikiran.
Berdasarkan latar belakang masalah dan landasan teori diatas maka hipotesis tindakan penelitian ini adalah "Diduga dengan menggunakan metode ekperimen dapat meningkatkan hasil belajar IPA pada materi benda dan sifatnya di Kelas IV SD Negeri 163083 kota Tebing Tinggi Tahun pembelajaran 2016/2017"

\section{METODE PENELITIAN}

Penelitian ini merupakan penelitian tindakan kelas (action research), karena penelitian dilakukan untuk memecahkan masalah pembelajaran di kelas. Penelitian ini juga termasuk penelitian deskriptif, sebab menggambarkan bagaimana suatu teknik pembelajaran diterapkan dan bagaimana haL yang diinginkan dapat dicapai.

Dalam penelitian tindakan ini menggunakan bentuk guru sebagai peneliti, penanggung jawab penuh penelitian ini adalah guru. Tujuan utama dari penelitian tindakan ini adalah untuk meningkatkan hasil pembelajaran di kelas dimana guru secara penuh terlibat dalam penelitian mulai dari perencanaan, tindakan, pengamatan, dan refleksi.

$\begin{array}{lll}\text { Tempat } & \text { penelitian } & \text { adalah } \\ \text { tempat yang } & \text { digunakan } & \text { dalam } \\ \text { melakukan } & \text { penelitian } & \text { untuk }\end{array}$
memperoleh data yang diinginkan. Penelitian ini bertempat di Kelas IV SD Negeri 163083 Jalan Basuki, Kecamatan Tebing Tinggi Kota, kota 
Tebing Tinggi Tahun pembelajaran 2016/2017

Waktu penelitian adalah waktu berlangsungnya penelitian atau saat penelitian ini dilangsungkan. Penelitian ini dilaksanakan pada bulan Juli sampai Oktober semester ganjil tahun pelajaran 2016/2017.

Subjek penelitian ini adalah siswa kelas IV SD Negeri 163083 Jalan Basuki, Kecamatan Tebing Tinggi Kota, Kota Tebing Tinggi tahun pembelajaran 2016/2017 yang berjumlah 22 siswa dengan rincian 13 laki laki dan 9 perempuan. Usia siswa rata rata berkisar 10-11 tahun. Objek pada penelitian ini adalah pemahaman siswa terhadap sifat benda padat, sifat benda cair, sifat benda gas, benda yang larut dan tidak larut dalam air, dan peristiwa perubahan wujud benda.

Teknik Analisis Data

$$
\text { Untuk mengetahui }
$$

keefektivan suatu metode dalam kegiatan pembelajaran perlu diadakan analisa data. Pada penelitian ini menggunakan teknik analisis deskriptif kualitatif, yaitu suatu metode penelitian yang bersifat menggambarkan kenyataan atau fakta sesuai dengan data yang diperoleh dengan tujuan untuk mengetahui prestasi belajar yang dicapai peserta didik juga untuk memperoleh respon peserta didik terhadap kegiatan pembelajaran serta aktivitas peserta didik selama proses pembelajaran.
Indikator Keberhasilan

Ada dua kategori ketuntasan belajar yaitu secara perorangan dan secara klasikal. Berdasarkan petunjuk pelaksanaan belajar mengajar, yaitu seorang peserta didik telah tuntas belajar bila telah mencapai skor $65 \%$ atau nilai 65 , dan kelas disebut tuntas belajar bila di kelas tersebut terdapat $80 \%$ yang telah mencapai daya serap lebih dari atau sama dengan $65 \%$. Untuk menghitung persentase ketuntasan belajar digunakan rumus sebagai berikut:

$$
P=\frac{\sum \text { Siswa.yang.tuntas.belajar }}{\sum \text { Siswa }} \times 100 \%
$$

\section{HASIL DAN PEMBAHASAN}

Dari data menunjukkan bahwa 10 soal yang diujikan kepada 22 siswa tidak ada soal tergolong tuntas. Dengan rincian soal nomor 1 terdapat 13 siswa yang tidak dapat menjawab soal dengan nilai persentase $59,09 \%$ dan 9 siswa dapat menjawab pertanyaan dengan persentase nilai $40,91 \%$. Soal nomor 2 terdapat 12 siswa yang tidak dapat menjawab soal dengan nilai persentase $54,55 \%$ dan 10 siswa dapat menjawab pertanyaan dengan persentase nilai $45,45 \%$. Soal nomor 3 terdapat 15 siswa yang tidak dapat menjawab soal dengan nilai persentase $68,18 \%$ dan 7 siswa dapat menjawab pertanyaan dengan persentase nilai $31,82 \%$. Soal nomor 4 terdapat 14 siswa yang tidak dapat menjawab soal dengan nilai 
ESJ VOLUME 8, NO. 3, DESEMBER 2018

persentase $63,64 \%$ dan 8 siswa dapat menjawab pertanyaan dengan persentase nilai $36,36 \%$. Soal nomor 5 terdapat 18 siswa yang tidak dapat menjawab soal dengan nilai persentase $81,82 \%$ dan 4 siswa dapat menjawab pertanyaan dengan persentase nilai $18,18 \%$. Soal nomor 6 terdapat 13 siswa yang tidak dapat menjawab soal dengan nilai persentase 59,09\% dan 9 siswa dapat menjawab pertanyaan dengan persentase nilai $40,91 \%$. Soal nomor 7 terdapat 9 siswa yang tidak dapat menjawab soal dengan nilai persentase 40,91\% dan 13 siswa dapat menjawab pertanyaan dengan persentase nilai $59,09 \%$. Soal nomor 8 terdapat 19 siswa yang tidak dapat menjawab soal dengan nilai persentase $86,35 \%$ dan 3 siswa dapat menjawab pertanyaan dengan persentase nilai $45,45 \%$. Soal nomor 9 terdapat 20 siswa yang tidak dapat menjawab soal dengan nilai persentase $90,91 \%$ dan 2 siswa dapat menjawab pertanyaan dengan persentase nilai $9,09 \%$. Soal nomor 10 terdapat 9 siswa yang tidak dapat menjawab soal dengan nilai persentase 40,91\% dan 13 siswa dapat menjawab pertanyaan dengan persentase nilai 59,09\%.

dilihat rata-rata nilai siswa masih memiliki tingkat ketuntasan dibawah $80 \%$ yaitu rata-rata nilai sebesar 35,45 sehingga baik secara perorangan maupun keseluruhan, kemampuan awal siswa masih tergolong belum tuntas. Dengan demikian dapat dikemukakan kesimpulan awal masih rendah dalam menguasai materi benda dan sifatnya.

Pada siklus I guru melakukan tiga kegiatan pembelajaran yaitu: kegiatan pendahuluan, kegiatan inti dan penutup. Kegiatan pendahuluan yang dilakukan dengan meliputi kegiatan guru memberikan orientasi berupa penyampaian sekilas tentang materi benda dan sifatnya. Berikutnya guru mengawali materi pelajaran dengan menyajikan materi menggunakan computer dan LCD, dengan tujuan memberikan apersepsi dan motivasi kepada siswa. Dengan demikian siswa akan memahami dan tertarik untuk menggali informasi dari materi tersebut.

Pada tahap pelaksanaan perencanaan pembelajaran pada siklus I ini, kegiatan guru difokuskan kepada pembelajaran dengan menerapkan metode eksperimen yang telah dirancang untuk meningkatkan kemampuan pemahaman siswa dengan cara siswa yang dibagi dalam kelompok yang terdiri atas empat atau lima siswa dengan latar belakang berbeda mengerjakan lembar tugas. Kelompok-kelompok ini menerima satu lembar tugas, menerima pujian dan penghargaan berdasarkan hasil kerja kelompok.

Tindakan

Tindakan yang diberikan guru pada siklus I ini diawali dengan menyaksikan tayangan tentang benda dan sifatnya kemudian penjelasan sedikit tentang benda dan sifatnya. 
Kemudian siswa yang dibagi dalam kelompok yang terdiri atas empat atau lima siswa dengan latar belakang berbeda mengerjakan lembar tugas. Kelompok-kelompok ini menerima satu lembar tugas, melakukan eksperimen tentang sifat benda dan benda-benda yang dapat larut dalam air dan yang tidak dapat larut dalam air, selanjutnya berdasarkan pengalaman saat melakukan percobaan, siswa memberikan penjelasan secara bergantian di depan kelas.

Setelah waktu berakhir, guru menginstruksikan kepada siwa untuk memperhatikan keterangan guru. Selanjutnya guru melakukan evaluasi dan penguatan. Guru memberikan beberapa pertanyaan sebagai bahan tes tertulis kepada siswa untuk dijawab dan setelah selesai dikumpulkan kepada guru. Setelah itu guru menutup pelajaran dengan melakuakan refleksi dan memberikan penguatan serta tindak lanjut kepada siswa.

Dari 10 tes yang diberikan kepada siswa hanya 4 soal yang dapat diselesaikan dengan baik dan sisanya 6 soal tidak dapat diselesaikan dengan baik. Untuk memastikan letak kesulitan yang dialami siswa saat mengerjakan tes hasil belajar maka dilakukan wawancara langsung dengan siswa yang mengalami kesulitan.

Pembahasan

Pembelajaran dengan metode eksperimen dapat meningkatkan hasil belajar siswa pada pelajaran ilmu pengetahuan alam pada materi benda dan sifatnya. Dengan menggunakan metode eksperimen, siswa dilatih untuk memahami dan mampu untuk melakukan aktivitas belajar dan menemukan sesuatu konsep dengan baik. Selain itu dengan menggunakan metode eksperimen siswa lebih lebih termotivasi dan semangat dalam mengikuti proses pembelajaran sehingga siswa lebih aktif dan benarbenar mampu melakukan tugas dari guru dengan sebaik-baiknya. Berdasarkan hasil pembelajaran siklus I dan II ini ternyata dengan menggunaka metode eksperimen dapat meningkatkan hasil belajar siswa pada materi Benda dan sifatnya.

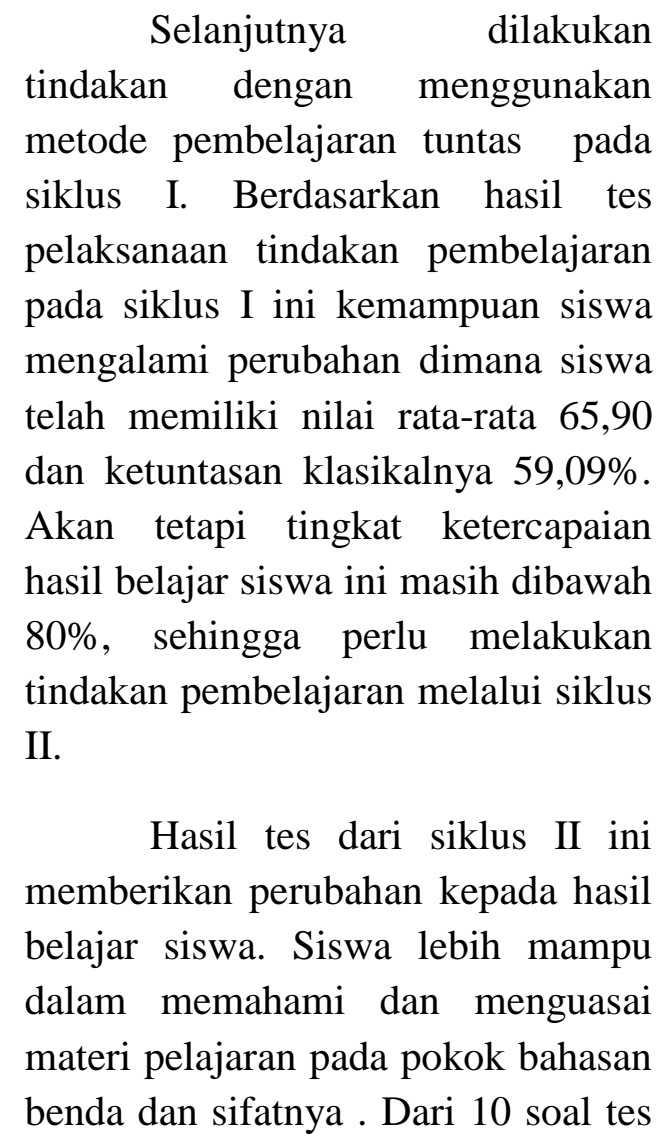


ESJ VOLUME 8, NO. 3, DESEMBER 2018

hasil yang diberikan kepada siswa 10 soal dapat diselesaikan siswa dengan baik, memiliki nilai rata-rata 89,54 dan ketuntasannya $100 \% \%$ atau telah berhasil siswa menjawab soal dengan benar. Dengan demikian dapat dinyatakan bahwa tingkat ketercapaian hasil belajar siswa pada siklus II secara keseluruhan tergolong telah berhasil yaitu $100 \%$ soal telah diselesaikan dengan baik oleh siswa.

Simpulan

Berdasarkan hasil penelitian dan pembahasan yang disajikan dapat ditarik kesimpulan bahwa:

1. Hasil penelitian degan menggunakan metode eksperimen terbukti dapat meningkatkan hasil belajar ilmu pengetahuan alam (IPA ) pada materi benda dan sifatnya siswa kelas IV SD Negeri 163083 Jalan Basuki, Kecamatan Tebing Tinggi Kota, Kota Tebing Tinggi tahun pembelajaran 2016/2017.

2. Rata-rata nilai hasil belajar siswa pada saat dilakukannya pretes dengan ketuntasan klasikal 9,09\% dengan rata-rata 35,45. Mengalami peningkatan dengan menggunakan metode eksperimen, hasil belajar siswa dapat ditingkatkan yaitu dapat dilihat dari hasil ketuntasan klasikal belajar siswa yang mencapai 59,09\% dengan rata-rata 65,90 pada siklus I dan meningkat menjadi $100 \%$ dengan rata-rata 89,54 pada siklus II.

3. Respon siswa terhadap penggunaan metode eksperimen menunjukkan sikap yang positif dan semua aspek telah terpenuhi. Aktifitas siswa selama pelaksanaan pembelajaran dengan menggunakan metode eksperimen pada pokok bahasan benda dan sifatnya menunjukkan bahwa nilai rata-rata hasil pengamatan siklus I mencapai 65,90 dan pada siklus II nilai ratarata hasil pengamatan meningkat menjadi 89,54/. Hal ini berarti bahwa aktivitas siswa selama pelaksanaan dengan menggunakan metode eksperimen berjalan dengan baik.

Dari hasil penelitian yang diperoleh dari uraian sebelumnya agar proses belajar mengajar IPA lebih efektif dan lebih memberikan hasil yang optimal bagi peserta didik, makan disampaikan saran sebagai berikut:

1. Untuk melaksanakan belajar dengan metode eksperimen memerlukan persiapan yang cukup matang, sehingga guru harus mempu menentukan atau memilih topik yang benar-benar bisa diterapkan dengan metode eksperimen dalam proses belajar mengajar sehingga diperoleh hasil yang optimal.

2. Dalam rangka meningkatkan prestasi belajar peserta didik, guru hendaknya lebih sering melatih peserta didik dengan berbagai metode, walau dalam taraf yang sederhana, dimana peserta didik nantinya dapat menemukan pengetahuan baru, memperoleh konsep dan keterampilan, sehingga peserta didik berhasil atau mampu 
Masdiana: Upaya Meningkatkan Hasil....

memecahkan masalah-masalah yang dihadapinya.

\section{DAFTAR RUJUKAN}

Ali, Muhammad. 1996. Guru Dalam Proses Belajar Mengajar. Bandung: Sinar Baru Algesindon.

Arikunto, Suharsimi. 1993. Manajemen Mengajar Secara Manusiawi. Jakarta: Rineksa Cipta.

Arikunto, Suharsimi. 1998. Prosedur

Penelitian Suatu

Pendekatan Praktek. Jakarta: Rineksa Cipta

Dahar, R.W. 1989. Teori-teori Belajar. Jakarta: Erlangga.

Departemen Pendidikan dan Kebudayaan, 1994. Petunjuk Pelaksanaan Proses Belajar Mengajar, Jakarta. Balai Pustaka.

Djamarah, Syaiful Bahri. 2000. Strategi Belajar Mengajar. Jakarta: Rineksa Cipta.

Hamalik, Oemar. 1994. Metode Pendidikan. Bandung: Citra Aditya Bakti.

Hasibuan. J.J. dan Moerdjiono. 1998. Proses Belajar Mengajar. Bandung: Remaja Rosdakarya.
Hudoyo, H. 1990. Strategi Belajar Mengajar IPA. Malang: IKIP Malang.

Kemmis, S. dan Mc. Taggart, R. 1988. The Action Research Planner. Victoria Dearcin University Press.

Margono. 1997. Metodologi Penelitian Pendidikan. Jakarta. Rineksa Cipta.

Ngalim, Purwanto M. 1990. Psikologi Pendidikan. Bandung: PT. Remaja Rosdakarya.

Rustiyah, N.K. 1991. Strategi Belajar Mengajar. Jakarta: Bina Aksara.

Sardiman, A.M. 1996. Interaksi dan Motivasi Belajar Mengajar. Jakarta: Bina Aksara.

Soekamto, Toeti. 1997. Teori Belajar dan Model Pembelajaran. Jakarta: PAU-PPAI, Universitas Terbuka.

Syah, Muhibbin. 1995. Psikologi Pendidikan, Suatu Pendekatan Baru. Bandung: Remaja Rosdakarya. 